ABDI: Jurnal Pengabdian dan Pemberdayaan Masyarakat ISSN: 2656-369X (Print), 2684-8570 (Online)

Volume 3 No. 2, Desember 2021

http://abdi.ppj.unp.ac.id/index.php/abdi

Email: abdi@ppj.unp.ac.id

DOI: https://doi.org/10.24036/abdi.v3i2.114

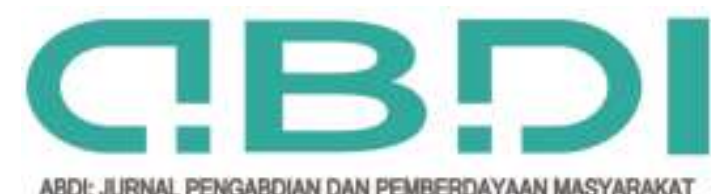

\title{
Pemberdayaan Pengrajin Tenun Ikat Melalui Inovasi Masker Tenun Sebagai Upaya Meningkatkan Pendapatan di Masa Pandemi COVID-19
}

\author{
Yudha Eka Nugraha ${ }^{1}$, Sri Endar Utami ${ }^{2}$ \\ ${ }^{1}$ Prodi Usaha Perjalanan Wisata, Politeknik Negeri Kupang \\ ${ }^{2}$ Prodi Akuntansi, Politeknik Negeri Kupang
}

E-mail: yudhaekanugraha@gmail.com, endar.utami@gmail.com

\begin{abstract}
Abstrak
Pandemi Covid-19 yang bertahan sejak awal tahun 2020 sampai semester pertama tahun 2021 ini telah membawa berbagai dampak bagi perekonomian Indonesia. Pelaku usaha didorong untuk menciptakan inovasi untuk bertahan di masa pandemic yang semakin kompetitif. Data menunjukkan, selama pandemic dunia usaha mengalami penurunan sebesar 94,69\%, 72,6\% diantaranya dialami oleh usaha kecil dan menengah. Salah satu sektor usaha yang mengalami dampak yakni UKM pariwisata yang mencapai penurunan sebesar $89,9 \%$. Kampoeng Tenun Alor merupakan kelompok pengrajin tenun ikat yang merupakan unit pendukung kegiatan pariwisata. Kondisi sebelum pandemic kelompok ini dapat menghasilkan omset sampai 50 juta per bulannya. Sedangkan pada masa pandemic, omset kelompok pengrajin tenun ikat menurun sampai 97\%. Penurunan omset ini berujung pada kesejahteraan kelompok pengrajin yang beranggotakan 10 orang dan keseluruhannya merupakan perempuan. Kegiatan pemberdayaan kelompok pengrajin Kampoeng Tenun Alor merupakan salah satu upaya untuk meningkatkan inovasi produk kreasi tenun ikat. Terinspirasi dari masker yang saat ini menjadi sebuah kebutuhan, maka inovasi masker tenun dipilih sebagai target sebagai pendapatan alternative selama pandemic berlangsung. Metode pelaksanaan pemberdayaan adalah ceramah, demonstrasi, tanya jawab, dan pelatihan dan pendampingan, dimana dalam pelatihan selama 2 hari dilakukan praktik menjahit untuk 10 orang anggota kelompok pengrajin tenun ikat. Hasil dari pelatihan ini, kelompok pengrajin mengalami peningkatan kreatifitas dibuktikan dengan peningkatan kompetensi dalam membuat masker tenun dan kreasi tenun lainnya untuk dipasarkan dan mendatangkan pendapatan untuk bertahan dimasa pandemic Covid-19.
\end{abstract}

Kata kunci: Masker Tenun, Pandemi, Pemberdayaan, Tenun Ikat, UKM

\section{Abstract}

The Covid-19 pandemic, which lasted from the beginning of 2020 to the first semester of 2021, has had various impacts on the Indonesian economy. Business actors are encouraged to create innovations to survive an increasingly competitive pandemic. The data shows that during the pandemic the business world experienced a decrease of $94.69 \%, 75 \%$ of which was experienced by small and medium enterprises. One of the business sectors that experienced the impact was the tourism SME which decreased by 89.9\%. Kampoeng Tenun Alor is a group of ikat craftsmen which is a unit to support tourism activities. The conditions before the pandemic, this group can generate a turnover of up to 50 million per month. Meanwhile, during the pandemic, the turnover of the group of weaving craftsmen decreased by $97 \%$. This decline in turnover has resulted in the welfare of a craftsman group that has 10 members, all of whom are women. The activity of empowering the Kampoeng Tenun Alor craftsman group is one of the efforts to increase the innovation of woven creations. Inspired by masks that are currently a necessity, the woven mask innovation was chosen as a target as an alternative income during the pandemic. The method of implementing empowerment was coaching, demonstration, training and assistance, where in the training for 2 days sewing practice was carried out for 10 members of the group of weaving craftsmen. As a result of this training, the group of craftsmen experienced increased creativity as evidenced by increased competence in making woven masks and other woven creations to be marketed and bring in income to survive the Covid-19 pandemic.

Key Word: Empowerment, Ikat Weaving, Pandemic, UKM, Weaving Mask

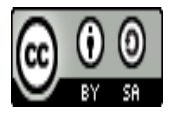


Yudha Eka Nugraha, Sri Endar Utami Pemberdayaan Pengrajin Tenun Ikat Melalui Inovasi Masker Tenun Sebagai Upaya Meningkatkan Pendapatan di Masa Pandemi COVID-19

\section{Pendahuluan}

Pada awal tahun 2020, seluruh dunia termasuk Indonesia, digegerkan dengan pandemi Corona Virus Disease 2019 (Covid-19). Implikasi yang ditimbulkan oleh pandemic sangat luas, terjadi pada berbagai macam sektor, termasuk UKM/UKMK (Usaha Kecil Menengah/Usaha Kecil Menengah dan Koperasi) (Laura, 2020; Rosita, 2020). Dampak paling terasa ketika Kemnaker (2020) merilis data yang menyatakan bahwa Pemutusan Hubungan Kerja (PHK) telah terjadi sebanyak 1,7 juta orang selama masa pandemic pertanggal 12 Mei 2020. Hal ini menunjukkan bahwa dampak yang ditimbulkan akibat pandemic ini tidak main-main. UMKM pun mengalami penurunan omset sampai dengan (Laporan Bank Indonesia, dalam Suherman 2020) merilis laporan UKM mengalami penurunan omset paling hebat, yaitu sekitar $72,6 \%$ selama pandemic berlangsung. Hal ini yang menyebabkan banyak pelaku usaha UKM semakin mengalami kesulitan untuk bertahan dan berakibat semakin banyaknya orang yang harus dirumahkan (Marlinah, 2020). Salah satu bidang yang paling terdampak COVID 19 adalah Pariwisata. Hampir diseluruh sektor yang terkait kepariwisataan seperti: penyedian makan dan minum, penyelenggaraan event, jasa pelayanan akomodasi perhotelan, dan bahkan kelompok pengrajin yang menyediakan souvenir oleh-oleh untuk menunjang kegiatan pariwisata. Data Bank Indonesia, 2020 menambahkan, UMKM yang paling terdampak adalah UMKM kerajinan dan pendukung pariwisata yang mencapai $89,9 \%$ di seluruh Indonesia. Sampai pada semester pertama tahun 2021, situasi pandemic masih berlangsung. Kegiatan perekonomian dilaksanakan dengan penyesuaian-penyesuaian era normal baru seperti diterbitkannya panduan CHSE (Clean, Safety, Health, and Environment) oleh Kementerian Pariwisata dan Ekonomi Kreatif pada tahun 2020, (Mardira, 2020). Pedoman ini merupakan sebuah upaya yang dilakukan oleh pemerintah agar perekonomian pada sektor pariwisata dapat berjalan kembali dengan mematuhi protocol kesehatan. Namun, upaya ini belum sepenuhnya dirasakan dapat mengembalikan kepercayaan wisatawan untuk pergi melancong dan berbelanja souvenir. Walaupun, survey menunjukkan sebanyak 44,6\% calon wisatawan berencana akan melancong setelah pandemic selesai (Redaksi, 2020). Jumlah pekerja UKM yang terdampak COVID 19 per 20 April 2020 sebanyak 2.084 .593 pekerja dari sektor formal maupun informal. Dari sektor informal data menunjukkan sejumlah 31.444 UMKM (Usaha Mikro, Kecil, Menengah) dengan 538.385 pekerja terdampak Covid-19 (Kuswantoro et al, 2020).

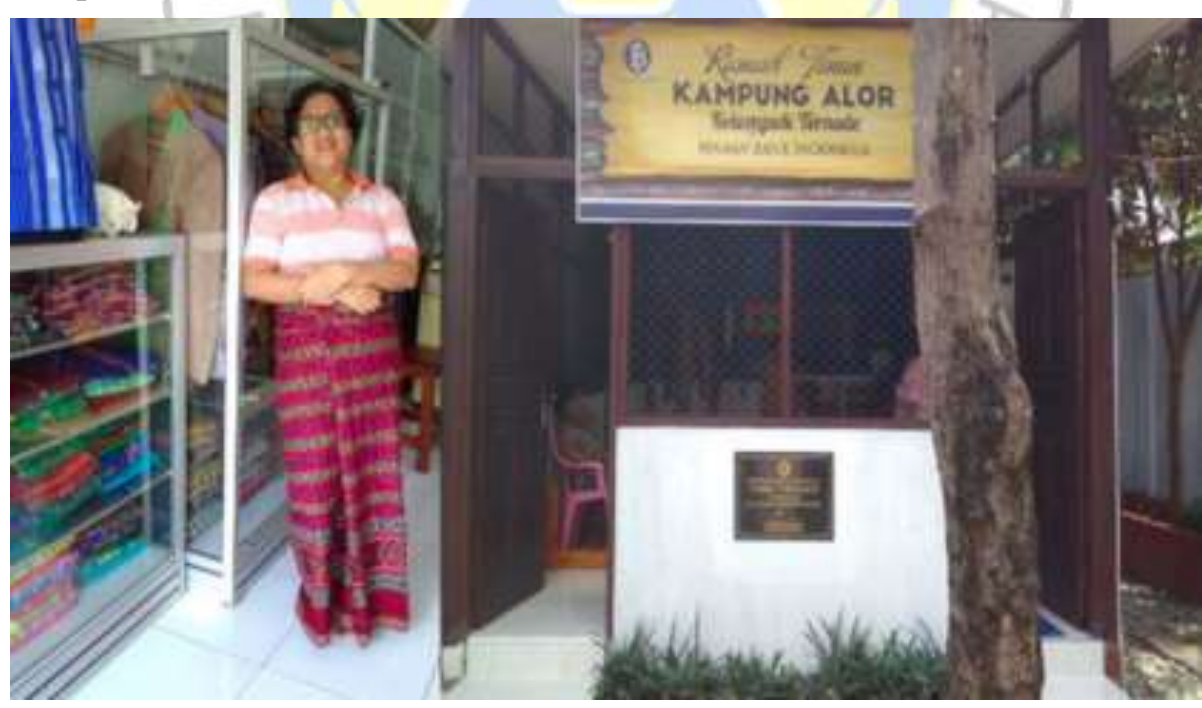

Gambar 1. Sasaran Pemberdayaan Kelompok Ternate Kampoeng Tenun Alor dan Ibu Ester Ketua Penggagas rumah pengrajin tenun ikat, dokumentasi pengabdian, 2021

Terkait dengan kondisi tersebut, salah satu UKM yang bergerak di sektor pariwisata adalah Kelompok Ternate di Kampoeng Tenun Alor Kota Kupang. Kelompok ini beranggotakan 10 orang perempuan yang memiliki minat yang sama dalam pelestarian tenun ikat Nusa Tenggara Timur sebagai daya tarik alternative bagi wisatawan yang berkunjung ke Kota Kupang. 
Kelompok Ternate di Kampoeng Tenun Alor beralamat di Jalan Cak Doko, Kecamatan Oebobo, Kota Kupang, Provinsi Nusa Tenggara Timur. Kelompok yang beranggotakan pengrajin tenun ikat khas NTT ini didirikan pada tanggal 23 Maret 2014 dan diresmikan oleh Deputi Gubernur Senior Bank Indonesia pada tanggal 29 November 2014. Kelompok ini dianggotai oleh 10 perempuan dan diketuai oleh Ibu Ester sebagai penggerak kelompok pengrajin tenun ikat Kampoeng Tenun Alor.

Kelompok Ternate di Kampoeng Tenun Alor didirikan dengan tujuan untuk melestarikan budaya yang ada di Provinsi Nusa Tenggara Timur yakni budaya kain tenun ikat. Saat ini tenun ikat mulai mengalami penurunan jumlah pengrajin sehingga semangat kelompok pengrajin tenun ini melanjutkan warisan budaya dari Provinsi NTT (Nasution, 2020). Kelompok pengrajin tenun ikat Kampoeng Tenun Alor memproduksi kain tenun ikat buatan tangan dengan berbagai motif dan warna yang beragam. Sebagian besar hasil tenun Kelompok Ternate bermotif Alor dan beberapa diantaranya bermotif asal suku Timor, Rote, Sabu, Ende dan wilayah NTT lainnya. Produk tenun ikat yang dihasilkan di Kampoeng Tenun Alor berupa selimut dan selendang yang dijual bagi wisatawan yang berkunjung ke Kota Kupang. Sebelum pandemic, pendapatan yang diperoleh cukup untuk memberi kesejahteraan pada kelompok pengrajin tenun ikat Kampoeng Tenun Alor. Jumlahnya bisa mencapai sekitar 50 juta perbulan. Namun, setelah pandemic muncul di awal tahun 2020 dan pemberlakuan pembatasan sosial berskala besar (PSBB) untuk mengurangi risiko penularan virus Covid-19, penjualan menurun drastic bahkan sampai 97\%. Kondisi ini sangat memprihatinkan mengingat kelompok pengrajin tenun ikat sangat bergantung dengan wisatawan yang datang untuk membeli hasil kerajinan tangan kelompok pengrajin. Upaya membuka toko berbasis daring pun sudah dilakukan namun wisatawan lebih banyak menyimpan uangnya karena fakta secara nasional pandemic mambawa dampak negatif bagi perekonomian Indonesia sehingga implikasi sampai kepada niat membeli yang menurun.

Pemberdayaan kelompok pengrajin tenun ikat muncul sebagai sebuah solusi untuk meningkatkan kembali motivasi kelompok pengrajin melalui pelatihan keselamatan dan kesehatan kerja saat menjahit kreasi tenun serta pelatihan pembuatan kreasi masker tenun ikat sebagai alternative pendapatan untuk kelompok pengrajin tenun ikat Kampoeng Tenun Alor, di Kota Kupang. Kegiatan ini terjadi atas kerjasama Politeknik Negeri Kupang melalui dukungan Kementerian Pendidikan, Kebudayaan, Riset dan Teknologi dalam kegiatan Pengabdian Kepada Masyarakat tahun anggaran 2021 dengan mitra Kelompok Ternate Pengrajin Tenun Ikat di Kampoeng Tenun Alor, Kota Kupang

\section{Metode Pelaksanaan}

Kegiatan pemberdayaan kelompok pengrajin tenun ikat di Kampoeng Tenun Alor Kota Kupang merupakan bentuk dari pengabdian masyarakat Politeknik Negeri Kupang yang memiliki metode dan beberapa tahapan pelaksanaan. Metode pelaksanaan pemberdayaan terbagi menjadi empat metode dalam pelatihan Keselamatan dan kesehatan kerja serta Pelatihan Pembuatan Masker dan Kreasi Berbahan Dasar Tenun Ikat, sedangkan dalam pelaksanaannya terdapat empat tahapan mulai dari tahapan koordinasi, tahapan pelaksanaan, tahapan pendampingan, dan tahapan evaluasi.

\subsection{Metode Pemberdayaan Kelompok Pengrajin Tenun Ikat Kampoeng Tenun Alor}

Dalam mengupayakan pemberdayaan yang maksimal, bermanfaat, dan berkelanjutan bagi mitra kelompok pengrajin tenun ikat di Kampoeng Tenun Alor, Kota Kupang, terdapat beberapa metode yang digunakan yakni: (a) Metode pendidikan masyarakat dengan ceramah, metode ini dipilih untuk dapat menyampaikan dasar-dasar materi dalam kegiatan pemberdayaan yang akan dilakukan. Dalam penelitian ini, pemberdayaan melalui metode pendidikan ceramah dilakukan saat penyampaian materi mengenai keselamatan dan kesehatan kerja bagi usaha menjahit dan materi dasar dalam menjahit kerajinan masker tenun dan kreasi dompet tenun. Metode ini dilakukan selama dua hari dengan melibatkan 2 pembicara dan 10 anggota kelompok pengrajin tenun ikat Kampoeng Tenun Alor; (b) Metode demonstrasi, yakni kelanjutan dari metode ceramah, setiap pembicara menunjukkan detail teori melalui langkah-langkah seperti pada materi pertama mengenai K3 untuk menjahit secara aman dan nyaman serta sosialisasi penerapan kerja sesuai prosedur alat kerja yang ergonomis. Kedua, demonstrasi mengenai langkah-langkah menjahit masker berbahan dasar kain tenun ikat serta kreasi dompet pesta

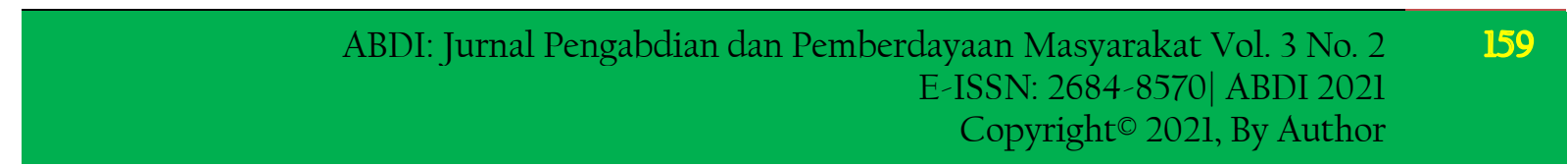


yang dikreasikan dari karton dan kain tenun ikat. (c) Metode tanya jawab, dilaksanakan pada akhir setiap sesi materi.

Tujuannya adalah untuk meningkatkan partisipasi kelompok pengrajin tenun ikat yang telah menerima materi sebelum masuk ke sesi praktik. Pada metode ini, partisipan dapat bertanya mengenai materi yang masih belum dimengerti, sehingga pembicara dapat menjelaskan kembali pada bagian materi yang belum dimengerti tersebut.; (d) Metode pelatihan dan pendampingan, yakni dilakukan dengan penerapan praktek membuat masker tenun dan kreasi dompet pesta dengan bahan tenun ikat. Peserta yang berjumlah 10 orang masing-masing memraktikkan pembuatan kedua produk tersebut sebagai bentuk nyata dari pemberdayaan. Praktik dimulai dari persiapan alat dan bahan, menentukan pola, menggunting bahan, serta menyatukannya dalam menjahit. Setelah seluruh peserta berhasil memraktikkan kreasi tenun maka kegiatan dilanjutkan dengan pendampingan yang dilaksanakan selama 3 bulan setelah pelaksanaan kegiatan pelatihan.

\subsection{Tahap Pelaksanaan Pemberdayaan di Kampoeng Tenun Alor}

Dalam melaksanakan pelatihan pemberdayaan kelompok pengrajin tenun ikat di Kampoeng Tenun Oebobo, terdapat empat tahapan yakni tahap koordinasi, tahap pelaksanaan, tahap pendampingan, dan tahap evaluasi.

Pada tahapan pertama atau koordinasi merupakan kegiatan yang dilakukan oleh tim pengabdian kepada masyarakat Politeknik Negeri Kupang dengan mitra untuk persetujuan pelaksanaan kegiatan. Selain itu, tahap koordinasi juga melakukan rapat kerja untuk menyusun kegiatan yang ingin dilakukan. Kegiatan koordinasi juga dilakukan antara tim pengabdian dengan Ketua LPPM (Lembaga Penelitian dan Pengabdian Kepada Masyarakat) Politeknik Negeri Kupang. Koordinasi ini dimaksudkan untuk perizinan surat tugas dan penyelenggaraan kegiatan serta menyampaikan undangan pelaksanaan kegiatan.

Tahapan kedua yakni pelaksanaan, pada kegiatan ini dilakukan pelatihan selama 2 hari dengan materi 1. Pelatihan Keselamatan dan kesehatan Kerja bagi Penjahit, dan 2. Pelatihan Pembuatan Masker Tenun dan Kreasi Tenun Ikat Lainnya. Instruktur pelatihan adalah ahli kerajinan tangan yang telah berpengalaman dalam membuat kreasi tenun.

Tahap selanjutnya adalah melakukan pendampingan, yakni setelah pelatihan selesai dilaksanakan. Pada tahapan pendampingan, kelompok pengrajin tenun ikat didampingi selama tiga bulan. Setiap minggu pada hari Jum'at tim pengabdian akan datang kembali ke lokasi Kampoeng Tenun Alor untuk melihat kemajuan hasil dari pelatihan pembuatan masker dan kreasi berbahan dasar tenun ikat. Selain itu, pada masa pendampingan, tim pengabdian memberikan bantuan berupa pembuatan website untuk membantu kelompok mitra memasarkan hasil kreasi tenun yang telah dibuat.

Tahap terakhir adalah evaluasi, yang didapatkan dari hasil penyebaran kuisioner mengenai keseluruhan program pemberdayaan yang telah dilaksanakan. Pada tahapan ini, tim pengabdian juga melakukan wawancara terfokus dengan ketua kelompok Kampoeng Tenun Alor untuk mengetahui perubahan-perubahan yang dirasakan oleh kelompok setelah mengikuti pemberdayaan ini.

\section{Hasil dan Pembahasan}

Pada bagian ini, akan dipaparkan mengenai hasil kegiatan pemberdayaan yang dilakukan pada dua kegiatan pelatihan yakni pelatihan keselamatan dan kesehatan kerja bagi penjahit dan pelatihan pembuatan masker tenun dan kreasi tenun lainnya.

\subsection{Pelatihan Keselamatan dan Kesehatan Kerja (K3)}

Pelatihan ini muncul sebagai sebuah upaya mencegah terjadinya kecelakaan kerja pada bidang menjahit. Bagi kelompok pengrajin tenun ikat yang saat ini akan dikembangkan usahanya melalui kreasi tenun, maka pengetahuan mengenai K3 di tempat kerja (rumah produksi tenun) wajib dilakukan (Mulyani, 2019). Pada umumnya, pelatihan ini menjamin keutuhan dan kesempurnaan kerja baik secara jasmaniah maupun secara rohaniah agar seluruh kegiatan kerja berjalan dengan nyaman dan produktif. Pelatihan ini terbagi kedalam enam sub-materi yang telah dikemas secara ringkas sehingga mudah 
untuk dipahami kelompok pengrajin tenun ikat di Kampoeng Tenun Alor, Kota Kupang. Peserta dalam kegiatan ini adalah seluruh anggota kelompok pengrajin yang berjumlah 10 orang.

Adapun sub-materi yang dibahas dalam pelatihan mengenai K3 yakni : (1) Mengetahui faktor hazard (sumber bahaya) dalam industri menjahit, (2) Mengetahui alat kerja, cara kerja, proses kerja, serta bagian yang dapat mengganggu kesehatan penjahit, (3) Mengetahui standar alat pelindung diri yang digunakan oleh penjahit, (4) Mengetahui pentingnya ketersediaan obat (P3K) Pertolongan Pertama Pada Kecelakaan di tempat kerja penjahit, (5) Mengetahui risiko penyakit yang muncul berhubungan dengan pekerjaan menjahit, (6) Pencegahan risiko bagi penjahit (Suparwo et al, 2019).

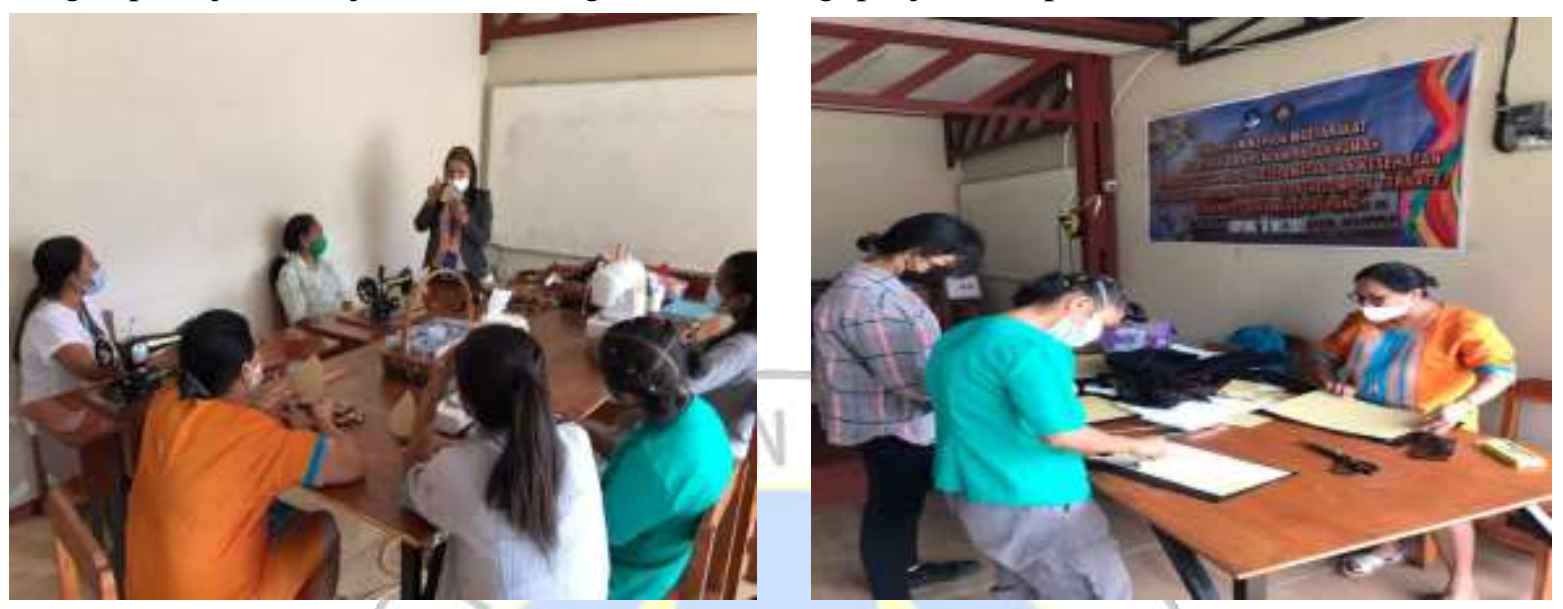

Gambar 2. Pelatihan K3 dan Demonstrasi K3 Bagi Penjahit

Keseluruhan materi diberikan pada hari pertama selama kurang lebih 3 jam materi secara ceramah dan juga demonstrasi. Instruktur mencontohkan penerapan K3 pada alat dan bahan menjahit yang ada didepan peserta. Setelah keenam sub-materi selesai diberikan, kelompok pengrajin antusias untuk bertanya kepada instruktur. Pertanyaan yang disampaikan pun beragam mulai dari penanganan pertama ketika kecelakaan kerja itu terjadi sampai dengan upaya yang dapat dilakukan agar selalu fokus selama bekerja sebagai penjahit. Pertanyaan-pertanyaan yang muncul menunjukkan bahwa pelatihan K3 yang diberikan memberikan stimulasi kepada kelompok pengrajin untuk mencerna materi. Dibuktikan dengan hasil angket yang telah disebarkan sebelum dan sesudah pelatihan terdapat perubahan yang signifikan dari respon peserta pelatihan K3. Tabel persepsi pelatihan K3 dapat dilihat pada tabel berikut.

Tabel 1. Hasil Pelatihan Keselamatan dan Kesehatan Kerja Bagi Penjahit Tenun Ikat

\begin{tabular}{|c|c|c|c|c|}
\hline No. & $\begin{array}{c}\text { Sub-materi } \\
\text { Pelatihan K3 }\end{array}$ & $\begin{array}{c}\text { Rerata } \\
\text { Pemahaman } \\
\text { Peserta } \\
\text { Terhadap } \\
\text { Materi } \\
\text { Sebelum } \\
\text { Pelatihan }\end{array}$ & $\begin{array}{c}\text { Rerata } \\
\text { Pemahaman } \\
\text { Peserta } \\
\text { Terhadap } \\
\text { Materi Sesudah } \\
\text { Pelatihan }\end{array}$ & Keterangan \\
\hline 1 & $\begin{array}{l}\text { Mengetahui faktor } \\
\text { hazard (sumber } \\
\text { bahaya) dalam } \\
\text { industri menjahit }\end{array}$ & $20 \%$ & $90 \%$ & $\begin{array}{l}\text { - Sebelum pelatihan hanya } 2 \\
\text { dari } 10 \text { peserta menjawab } \\
\text { pertanyaan dengan benar. } \\
\text { - Setelah pelatihan } 9 \text { dari } 10 \\
\text { peserta menjawab pertanyaan } \\
\text { dengan benar. }\end{array}$ \\
\hline
\end{tabular}


Yudha Eka Nugraha, Sri Endar Utami Pemberdayaan Pengrajin Tenun Ikat Melalui Inovasi Masker Tenun Sebagai Upaya Meningkatkan Pendapatan di Masa Pandemi COVID-19

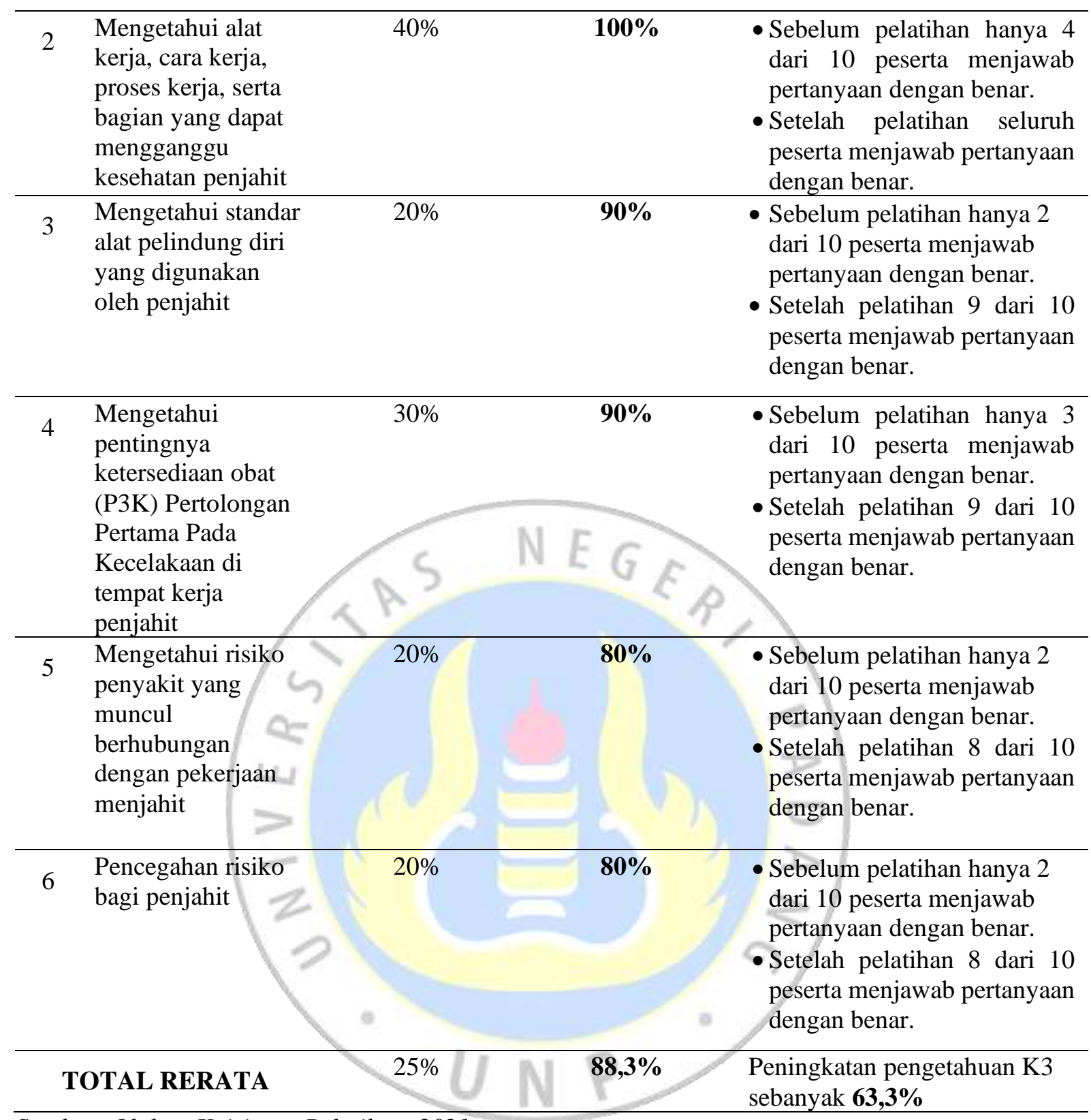

\section{Sumber: Olahan Kuisioner Pelatihan, 2021}

Hasil yang ditunjukkan pada tabel 1 menunjukkan bahwa terjadi peningkatan pengetahuan sebanyak 63,3\% selama pelatihan K3 dilakukan. Hal ini terjadi karena beberapa faktor diantaranya adalah antusiasme kelompok pengrajin selama pelatihan yang fokus dan mengikuti materi secara serius. Selain itu, bidang menjahit adalah sesuatu yang baru terutama dalam perjalanan karir kelompok pengrajin dalam memproduksi hasil kreatifitas berbahan dasar tenun ikat. Sehingga aktivitas ini tidak dilewatkan oleh setiap anggota kelompok pengrajin. Adapun hal yang menyebabkan tantangan dalam mengikuti pelatihan salah satunya adalah umur diatas 55 tahun pada anggota kelompok yang membatasi sehingga dalam mengisi kuisioner mengalami kesulitan.

\subsection{Pelatihan Pembuatan Masker Tenun dan Inovasi Kreatif Berbahan Tenun Ikat}

Kegiatan pemberdayaan dilanjutkan dengan pelatihan pembuatan masker tenun dan inovasi kreatif berbahan dasar tenun ikat. Kegiatan ini dilaksanakan setelah pelatihan K3 sampai dengan hari berikutnya. Instruktur yang diundang merupakan penjahit yang memiliki keahlian dalam membuat 
Yudha Eka Nugraha, Sri Endar Utami Pemberdayaan Pengrajin Tenun Ikat Melalui Inovasi Masker Tenun Sebagai Upaya Meningkatkan Pendapatan di Masa Pandemi COVID-19

kreasi tenun ikat. Sebelum pelatihan ini dimulai, alat dan bahan yang dibutuhkan telah dipersiapkan. Mulai dari mesin jahit yang digunakan untuk praktek sejumlah 5 unit, kain furing, karet untuk tali masker, alat menjahit, dan komponen yang paling penting yakni tenun ikat. Tenun ikat yang digunakan untuk keperluan pelatihan praktik kali ini adalah tenun ikat sisa produksi pembuatan baju. Kelompok pengrajin seringkali menyimpan sisa pembuatan baju tenun untuk dimanfaatkan pada waktu seperti pelatihan ini.

Setelah alat dan bahan disiapkan, peserta mulai dipandu untuk membuat pola masker terlebih dahulu (Effendi et al., 2021). Pola masker yang akan dibuat bentuknya sederhana dimulai dari menggambar pola diatas karton. Setelah itu, karton dilapisi furing dan dijahit pada tahapan pertama (Setiadi et al., 2021). Setelah selesai menjahit karton yang dilapisi furing (Putra et al., 2020), tambahkan karet masker dan tenun ikat yang sudah digunting juga sesuai pola yang sebelumnya dibuat. Setelah itu jadilah masker tenun ikat yang siap digunakan. Pelatihan pembuatan masker tenun ini tidak memerlukan waktu yang lama. Instruktur yang handal dapat memandu kegiatan selama kurang lebih satu jam kegiatan. Proses yang memakan waktu adalah mendampingi satu persatu peserta yang berjumlah 10 orang. Pada awal pendampingan, terlihat beberapa anggota kelompok pengrajin belum mahir menggunakan mesin jahit. Namun, dengan pendampingan yang diberikan instruktur, perlahan setiap anggota mampu untuk memproduksi setidaknya satu buah masker berbahan dasar tenun ikat sebagai luaran dari pelatihan ini.

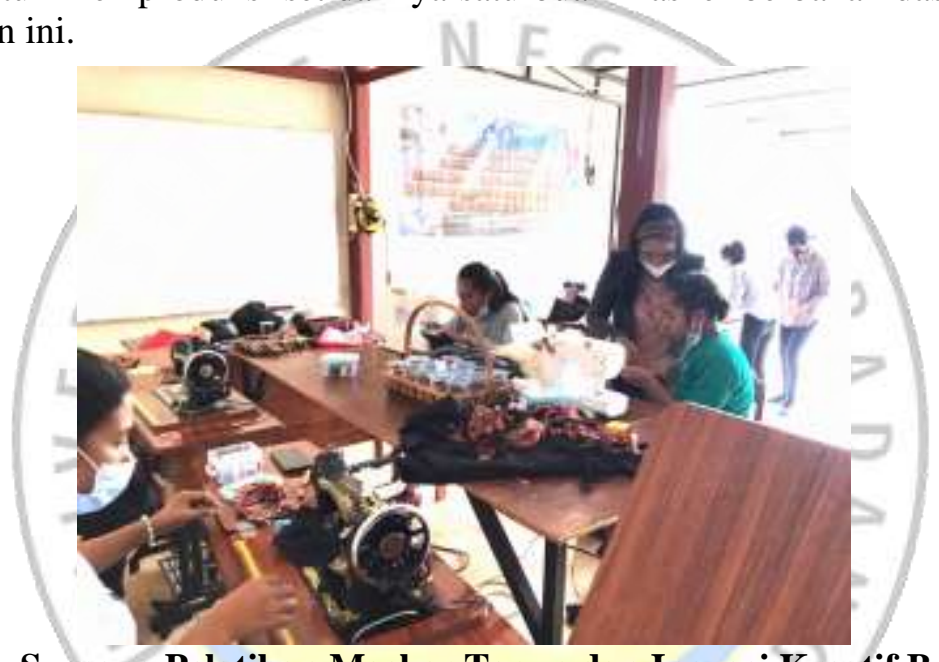

Gambar 3. Suasana Pelatihan Masker Tenun dan Inovasi Kreatif Berbahan Tenun Ikat

Selanjutnya, instruktur memandu kembali peserta untuk membuat inovasi kreasi tenun ikat untuk menjadi produk lainnya yakni dompet pesta. Hampir sama dengan masker tenun, pembuatan dompet pesta berbahan dasar tenun ikat tidaklah rumit.
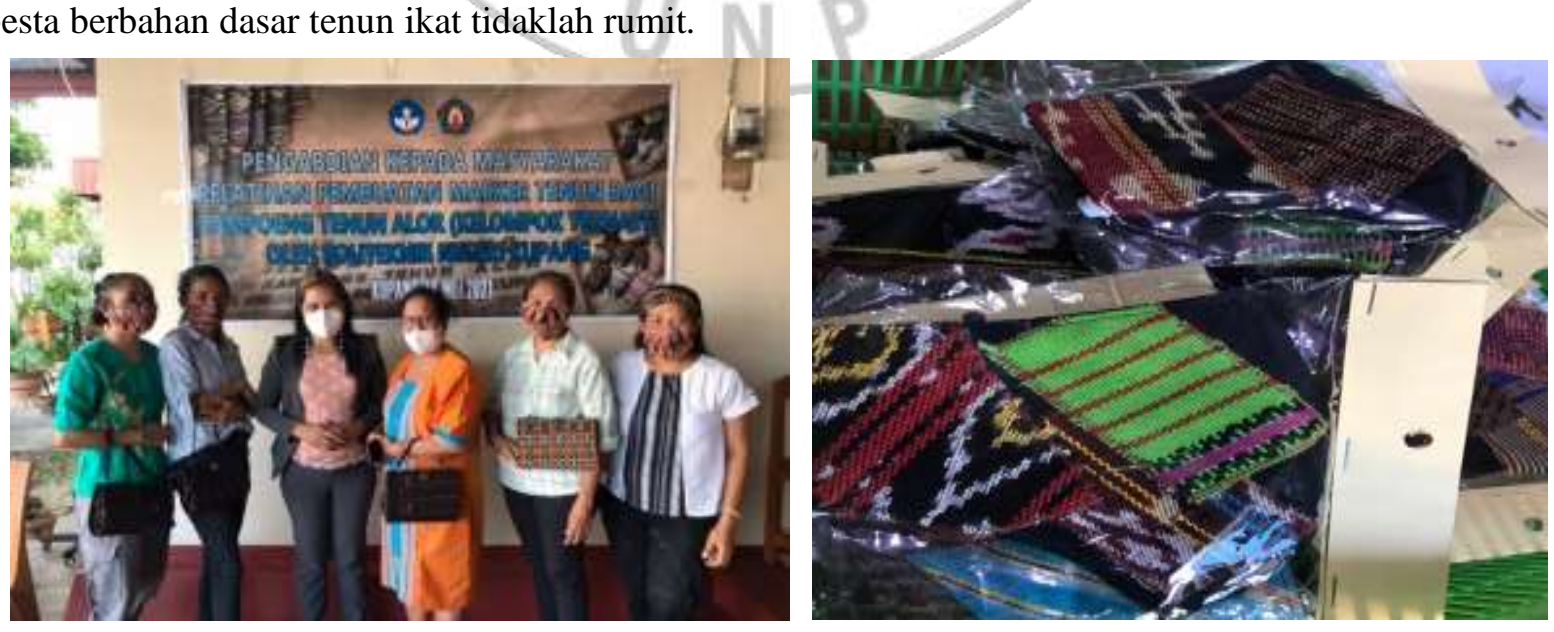

Gambar 4. Hasil Pelatihan Berupa Masker Tenun Berbahan Kain Tenun Ikat 
Namun, dibutuhkan strategi yang baik agar hasil eksekusi karya kreatif menjadi menarik dan bernilai ekonomis. Bahan yang digunakan hampir sama, selembar karton berbentuk persegi Panjang, lem, tali, dan tenun ikat sebagai komponen utamanya. Peserta terlihat antusias untuk mengikuti pelatihan kreasi tenun ini. Dibuktikan dengan peserta yang lupa dengan waktu dan meminta waktu tambahan kepada panitia tim pengabdian untuk dapat menyelesaikan pelatihan sampai bisa menguasai dua produk kreasi tenun yakni masker dan dompet pesta. Berkat ketekunan dan semangat peserta kelompok pengrajin tenun ikat di Kampoeng Tenun Alor serta instruktur yang mendampingi, kegiatan pelatihan dapat berjalan dengan baik. Peserta sangat senang dan berharap agar terus didampingi agar produk yang dihasilkan dapat bernilai ekonomis dan meningkatkan pendapatan di masa pandemic yang masih berlangsung seperti saat ini. Diakhir pelatihan ini, masing-masing peserta mampu untuk membuat dua produk yakni masker dan dompet pesta. Beberapa diantaranya diabadikan seperti gambar berikut:

\section{Kesimpulan}

Pemberdayaan kelompok pengrajin tenun ikat (Ternate) di Kampoeng Tenun Alor, Kota Kupang telah terlaksana dengan baik. Kegiatan pemberdayaan dilaksanakan pada dua pelatihan yakni (1) Pelatihan Keselamatan dan Kesehatan Kerja Bagi Penjahit yang menunjukkan hasil bahwa sebanyak $88,3 \%$ peserta pelatihan dapat memahami materi dan mempraktikkannya ketika mulai melakukan kegiatan menjahit, dan (2) Pelatihan Masker Tenun dan Inovasi Kreatif Tenun Ikat Berupa Dompet Pesta dengan hasil setiap peserta mampu untuk membuat masing-masing satu produk masker dan produk dompet pesta. Selanjutnya, berdasarkan pengamatan selama melaksanakan kegiatan pelatihan, peserta terlihat antusias dan mempunyai keinginan yang tinggi untuk belajar dan mempraktekkan apa yang didapat selama pelatihan. Adapun tujuan kegiatan ini tercapai dengan dihasilkannya produk baru hasil inovasi kelompok pengrajin tenun ikat berupa masker tenun dan dompet pesta berbahan dasar tenun. Kesepuluh anggota kelompok pengrajin tenun ikat menjadi terampil untuk membuat kreasi tenun tersebut berkat dukungan instruktur yang mendampingi selama kegiatan pelatihan berlangsung. Selain itu, pelatihan ini membuat kelompok pengrajin tenun ikat berkomitmen untuk menjadikan masker tenun dan dompet pesta berbahan tenun sebagai produk unggulan yang akan dijual sebagai solusi meningkatkan pendapatan di masa pandemic covid 19. Kegiatan ini juga tidak akan terlaksana tanpa dukungan berbagai pihak terutama dukungan Kementerian Pendidikan, Kebudayaan, Riset, dan Teknologi melalui hibah kompetitif Pengabdian Kepada Masyarakat, juga kerjasama yang baik antara Politeknik Negeri Kupang dan Mitra dari Kampoeng Tenun Alor Kota Kupang.

\section{Daftar Pustaka}

Buana, M. (2018). Lestarikan Nilai Tenun Ikat Perkuat Ekonomi Kreatif, https://www.metrobuananews.com/2018/10/03/lestarikan-nilai-tenun-ikat-perkuat-ekonomikreatif/

Effendi, M. S., Farida, F., Wahyuni, N., Trisnawati, N., \& Marhalinda, M. (2021). Kreasi Masker Fashionable Di Era Pandemic (RW 02 Kel. Rawasari, Kec. Cempaka Putih, Jakarta Pusat). IKRA-ITH ABDIMAS, 4(2), 60-67.

Kemenaker. (2020). Menaker: Badai Pasti Berlalu, Panggil Kembali Pekerja yang ter-PHK Nanti, Diakses pada 20 Oktober 2020 dari https://www.kemnaker.go.id/ news/detail/menaker-badaipasti-berlalu-panggil-kembali-pekerja-yang-ter-phk-nanti, 2020

Kuswantoro, K., \& Alfi, I. (2020). Strategi Keuangan UMKM Cilacap Menghadapi Pandemi Covid 19 (Studi Kasus UMKM Kabupaten Cilacap). Jurnal Teknologi dan Bisnis, 2(1), 40-51.

Laura Hardilawati, W. (2020). Strategi Bertahan UMKM di Tengah Pandemi Covid-19. Jurnal Akuntansi dan Ekonomika, 10(1), 89-98.

Mardira. (2020). Apa Itu CHSE Pariwisata dan Ekonomi Kreatif. https://www.okezone.com/tren/read/2020/10/09/620/2291190/apa-itu-chse-pariwisata-danekonomi-kreatif 
Yudha Eka Nugraha, Sri Endar Utami Pemberdayaan Pengrajin Tenun Ikat Melalui Inovasi Masker Tenun Sebagai Upaya Meningkatkan Pendapatan di Masa Pandemi COVID-19

Marlinah, L. (2020). Peluang dan Tantangan UMKM Dalam Upaya Memperkuat Perekonomian Nasional Tahun 2020 Ditengah Pandemi Covid 19. Jurnal Ekonomi, 22(2), 118-124.

Mulyani, Y., Gardiarini, P., \& Karim, S. (2019). Penerapan Kesehatan Keselamatan Kerja (K3) di UMKM Laundry Balikpapan. Jurnal ABDINUS: Jurnal Pengabdian Nusantara, 2(2), 122-128.

Nasution, L. (2020). Efektifitas HKI Sebagai Pelindung Industri Kreatif dan UMKM Di Tengah Pandemi Covid-19. Adalah, 4(1), 1-10.

Putra, I. W. D., \& Yanthi, N. N. S. (2020). Melukis Masker (Berkreasi Dalam Pandemi). Segara Widya: Jurnal Penelitian Seni, 8(2), 127-133.

Redaksi. 2020. Pra Survey Keinginan Segera Melancong Setelah Pandemi Pergi. https://lenteratoday.com/pra-survey-keinginan-segera-melancong-setelah-pandemi-pergi/

Rosita, R. (2020). Pengaruh pandemi Covid-19 terhadap UMKM di Indonesia. Jurnal Lentera Bisnis, 9(2), 109-120.

Setiadi, V. S., Riyanti, M. T., Indralaksemi, I., \& Triwardoyo, B. (2021). Pelatihan Kain Shibori Untuk Membuat Kreasi Masker Dan Tas Belanja. Jurnal Abdi Masyarakat Indonesia, 3(1), 62-70.

Suherman, Irwan. 2020. 30 Juta Pelaku Pariwisata dan Ekonomi Kreatif Terpuruk, Sandiaga Uno: Harus Segera Dibantu. https://www.pikiran-rakyat.com/nasional/pr-011174180/30-juta-pelakupariwisata-dan-ekonomi-kreatif-terpuruk-sandiaga-uno-harus-segera-dibantu

Suparwo, A., Suhendi, H., \& Shobary, M. N. (2019). Pengelolaan Manajemen Keselamatan Dan Kesehatan Kerja Pada UMKM Bandung Indo Garmen. Jurnal Abdimas BSI: Jurnal Pengabdian Kepada Masyarakat, 2(1), 10-21. 

